\title{
Financial Innovation and Economic Growth in Nigeria a Sectoral Analysis
}

\author{
Ogunsakin Sanya (Ph. D) Alabi Bakare Olatunji PH.D Student \\ Ekiti State University, Ado-Ekiti, Department of Economics, Faculty of the Social Sciences
}

\begin{abstract}
This study examined the effect of financial innovation on different components of real output of some selected sectors of Nigerian economy between 1990 to 2018 using panel vector Error Correction as estimation technique. Data for the study were sourced from Central Bank of Nigeria statistical Bulletin and Bureau of Statistics. Results obtained from our various estimations showed that there is long-run co-movement between sectoral real output and financial innovation variables. Result from VAR revealed that sectoral output responded heterogeneously to shocks emanating from financial innovation. Take for instance, the responses of manufacturing and Agricultural sectors to shocks from financial innovation variables were positive and significance while responses of service and construction sectors were positive but insignificant. Results obtained from variance decomposition showed that the most essential financial innovation variables which have much influenced on sectoral output in Nigeria during the study period are Automated teller machine ATM) and point of sale transaction (POS). Based on these findings, the study therefore, concludes that financial innovation has effects but not a significant effect on sectoral real output in Nigeria. The study recommends that more regulatory guide-lines should be formulated for financial institutions to perform their financial intermediation functions effectively.
\end{abstract}

Keywords: Financial innovation, sectoral real output, VECM and Nigeria

DOI: $10.7176 / \mathrm{JESD} / 11-16-14$

Publication date:August $31^{\text {st }} 2020$

\section{SECTION ONE}

Introduction

The broad objective of financial system in every nation is to facilitate, mobilize, allocate and deploy both economic and financial resources spatially and across time in an in certain environment. Banks are the backbone for financial system in any countries around the world Muhammed (2016). This shows that financial system development is an integral components of the link between real and monetary sectors of every economy. A well developed and well structured financial system will influence economy growth positively.

In the last two decades, the global financial system has been characterized by a strong innovation in the secondary markets which necessitate the coming of new financial services and products delivery that enable financial intermediaries to hedge their specific risk Karo (2013) Global financial liberalization process has accelerated competitions in the banking industries which has really informed series of financial innovations.

Nigerian financial system like other developing countries has been growing with technological advancement and innovative in financial services and product delivery. Nigeria financial system has gone through series of reforms since introduction of structural adjustment programme (SAP). Because of this structural shift in the economic and to meet up with changes in the global financial systems, there is an alteration in the traditional financial system which paved way for financial innovations products such as ATMs, phone bunking, internet banking, debt cards, credit cards, agency banking and smart card applications. These new products have almost replaced the traditional methods of cheque book for current accounts and pass-book for savings accounts.

Moreover, despite the fact that Nigerian financial system embraced financial innovation in its financial services and produced delivery, this has not really generates positive change in terms of customers needs. Take for instance, transaction errors, long queuing at banks. Insecurity, network failure and other issues have been constitutes blocking stone in using banking services. This has however reduces customer perception on the quality of service offered and hence reduces bank credibility and profit ability as noted by Joseph et al (2013).

In the last two decates, Nigerian financial system has grown gradually and negatively in some period. This has really necessitated series of financial sector reforms to reposition and to enhance they performance to effectively perform their function of financial intermediation. Despite of all these reforms, much impacts of financial services have not been noticed on over-all performance of Nigerian economy.

Therefore, it is either financial system is irrelevant on economic growth or other sectors of the Nigerian economy have undermined it. With this, the relative growth recorded might be stimulated by other sectors, such as Agriculture, manufacturing. Trade and commerce and mining sectors.

In recent times, there have been agitations on the sectoral effects of financial innovation on the general performance of economies. The fact that the response of sectors to shocks emanating from financial services and product delivers may not be the same. This however has implications for apex bank to consider the outcome of their various policies on the various sectors of the economy. Understanding the responses of the disaggregated 
components of the real economy is essential given that different sectors have different capital intensities that generate different responses in sectoral output from financial services. These differences in responses are largely disguided at an aggregated level thus making the disaggregated method more informative than aggregate approach for the purpose of analyzing the transmission channel of financial services.

The brond objective of this paper is to investigate the effect of financial innovation of sectoral output of Nigeria economy.

The rest of the paper is structured thus, this introductory chapter is followed by section two that discusses Nigerian economy and financial system and empirical literature. Section three presents methods and materials. Section four centres on results and discussion while section five concludes the paper.

\section{SECTION TWO \\ SECTION II}

Theoretical Issues

There are theories propounded by researchers and scholars as regards the relationship between financial development and economic growth. The most famous among these theories are supply-leading theory, Demandfollowing theory, feedback relationship theory and no causal relationship theory.

The supply leading theory was developed by Schumpeter (1911), and later integrated and advanced by Mckinnon (1973) and Shaw, (1973). The central focus of this theory is that financial development stimulates economic growth. This is made possible because financial sector of the economy mobilizes savings, facilitates exchange of goods and services, generates information and allocates capital and betters risk management for efficient methods of production. However, the idea of Schumpeter (1911) as regards supply leading theory did not go down well with Robinson, (1952) Greenwood and Jovanovic (1990) and Stiglitz (1994) when they propounded the Demand-Following Theory, they were of the opinion that not financial development that causes economic growth but economic growth leads to financial development. In their views, they argued that development in the real sector of every economy stimulates demand for financial services that metamorphoses to the establishment of financial intermediaries. According to this theory, economic growth generates an increase in income, consumption and savings and this then brings about demand for financial intermediation. That is, mobilizing resources from surplus sector of the economy to the deficit sector. Therefore, the causality that runs between financial development and economic growth is unidirectional. To further advance demand following theory, feedback relationship theory was introduced by Robinson (1950), Berthelemy and Varoudakis (1996). In this, the promoter of this theory were of the view that causality that runs between economic growth and financial development is bidirectional. That is, financial development stimulates economic growth as economic growth too brings about financial development.

To conclude theories on the relationship between economic growth and financial development, a particular theory came up, no causal relationship. The promoters of this theory, Lucas, (1908) argued that no causality runs between economic growth and financial development. This theory centres on the premises that economic growth is being stimulated by improvement in the real sector of the economy. That is, financial sector development is of no relevant to economy growth in modern economies.

NIGERIAN ECONOMY AND FINANCIAL SYSTEM Since the discovery of crude oil in Nigeria at Olobiri in commercial quantity in the late 1960s the Nigerian economy has been mostly depend on export of crude oil for foreign exchange earnings and revenue essentially sales of crude oil which responsible for almost 95 percent of export earrings and about 85 percent of government revenues. Despite this, the contribution of this sector to the GDP is around 17.85 percent Energy Information Administration (2009).

The Nigerian economy has recorded positive growth rate continuously since the advent of democracy which was truncated in late 2016 as a result of reduction in crude oil price at international oil market. This however led the economy to recession between the second quarter of 2016 till last quarter of 2018 when the economy marginally out of recession. The average growth of Nigerian economy before recession of 2016 stood around 6.33 percent against world real outfit growth of 2.72 percent. Nigeria is described as an upper - middle income country according to the world Bank (2018) located in Western African. Nigeria is the largest economy in Africa follows by South Africa. Its economy is characterized as a oil rich country. Therefore, Nigerian economy is grently tired with the behaviour of crude oil price at international oil market. Nigerian economy fails to articulate its resources into economic prosperity due to macroeconomic instability, mis-management of resources and mis-priotization. Failure of the economy to sustain its growth rate has been as a result of oil price fluctuation, political instability, economic instability, high unemployment level galloping inflation etc. Nigerian economic growth has been volatile. The growth recorded is not sufficient to transpire into poverty reduction and relative income equality.

The 2019 election posed a great uncertainty that responsible for the financial sector in replicating to a continuous increase in income among all fixed income securities. The reduction in government revenue due to reduction in crude oil price at international oil market led to foreign exchange scarcity and increase in domestic general price. This however brought about slow economic growth since 2018. To curb this, Nigerian monetary 
authority introduced different policy interventions with objective of reducing the demand for foreign currency and preserving the naira devaluation. To complement thus, liquidity ratio was placed at 31 percent for both public and private deposits. Banks were equally denied of accepting foreign cash deposits from their customers, as well as removal of 41 items from accessing foreign exchange at the official market rate. The recent reduction in crude oil price have seriously affected banks performance in the country. Therefore, the is likelihood of increase in nonperforming loans in most banks which invariably might lead to low revenue and profit. Akinkunbi, (2017)

\section{Empirical literature}

The issue of the relationship between financial development and Economic growth have been so contentions and perennial since it had been identified by Schumpeter (1911). The exact nature of the relationship is still controversial. Therefore, it is essential to present some of these studies empirically to provide guides and directions for the model of this present study. Ahmed and Juliot (2015) Investigated the relationship between financial development and economic growth between 1995 to 2013 in Maghreb countries. The countries considered in the study are Morocco, Tunisia, Algeria, Libya and Mauritania). The study employed panel co-integration as estimation technique. Finding from the study showed that financial development positively and significantly impacted itself but did not produce any impact on economic growth. In the same line of study, Ahmed (2010) examined the relationship between financial development and economic growth in 15 sub-Saharan Africa countries between 1976 to 2005. The study made use of Vector Error Correction Model (VECM) and Granger causality as estimation techniques. Finding from this study revealed that there was long-run relationship between financial development variables and economic growth in the selected countries. Advancing literature on this topic, AINasser, Kagochi and Kebede (2013) examined the relationship between financial development and economic growth in 7 sub-Saharan Africa countries between 1991 to 2007 using VAR and Grange causality test as estimation techniques. Results showed that there was uni-directional causality from economic growth to bank. Also, feedback causality was discovered between stock market development indicators and economic growth in the selected sub-Saharan Africa countries. Renzi and Schmiedu (2013) used (GMM) to examine the relationship between retail payment (technological innovation) and the real economy in $27 \mathrm{Eu}$ countries between 1995 and 2007. Finding from this study showed that technological innovation which was measured by ATM's and (POS) showed positive and significant relationship with economic growth which was measured by GDP per-capital. In a related study Rauf and Qiang (2014) studied the impact of e-banking system on the performance of Pakistan commercial bank. In the study, commercial banks performance was measured by return on assets, equity and interest margin. Finding from this study showed that e-banking significantly and positively impacted commercial bank performance in Pakistan during the study period. Also, Philippas and Siriopoulos (2007) studied the relationship between financial innovation and the operational risk in business in some selected countries. The study employed stochastic model as estimation technique. Finding from this study revealed that acceleration in production level gives room for financial innovation. Odularu and Okunrinboye (2009) investigated the effects of financial innovations on money demand function in Nigeria after structural adjustment programme. The study made use of Egle and Granger Two-step conintegration as estimation technique. Result from this study showed that financial innovation has really altered the stability of money demand function in Nigeria during the study period. Anthony and Anthony (2012) employed Granger causality test to Investigate the relationship between financial innovation and economic growth in Ghana between 1953 to 2009. The study equally employed ARDL to complement Granger causality Test. Finding from this study showed that financial innovation only have positive effect on the growth of Ghanaian economy in the short-run. However, results from Granger causality showed that causality runs from financial innovations to economic growth. In a related study, Joshua Abo (2005) studied the relationships between effect of technological innovations on banking services in Ghana. Finding from this study showed that technological innovation enhanced the performance of banking industry in Ghana. Muthoni (2013) studied the determinants of performance of both banking and non banking financial institutions in Kenya between 2008 to 2012 using both descriptive and inferential statistics as estimation techniques. Finding from this study showed that financial innovation is one of the major determinants of performance of both banking and non banking financial institutions in Kenya. Dunne and Kesekende (2016) examined the impact of financial innovation on the stability of money demand function in sub-Saharan Africa between 1980 and 2013 using panel co-integration as estimation technique. Finding from this study showed that financial innovation has actually altered the stability of money demand function but the alteration was not significant. Giriyophen (2018) investigated the relationship between financial innovation and gross fixed capital formation in African countries between 2000 and 2016. Finding from this study revealed that financial innovation did not significantly impact gross fixed capital formation in African countries. To enhance the study on the relationship between financial innovation and macroeconomic variables. Ogunwale (2019) studied the interaction among financial development and manufacturing industry performance in Nigeria between 1998 to 2017 using vector error correction model as estimation technique. Finding from this study showed that the response of variables used to capture manufacturing industry performance to shock from financial development variables was positive but not significant. Also, Ogunsakin (2019) investigated the 
relationship among financial innovation, money demand function and output growth in sub-Saharan Africa countries between 1990 to 2016 using panel VCEM as estimation technique. Finding from this study revealed that financial innovation did not alter the stability of money demand function. Also, financial innovation did not significantly contribute to the growth of Sub-Saharan Africa economies during the study period. James (2014) investigated the effects of financial innovation on the financial performance of commercial banks in Kenya between 2008 - 2018 using both descriptive and inferential statistics. Finding from the study showed that financial innovation has great impact on the financial performance of the banks. In the same line of study Aysel $G$ and Fatina D. T (2017) studied the analysis of the relationship between financial innovation and the performance of Turkish Banking system between first quarter of 2005 and second quarters of 2015 using ordinary least square as estimation technique. Finding from the study revealed that only credit card usage has a significant positive impact on ROA, ROE and NIM. The positive impact of ROA and ROE increases the profitability and that the performance of banking system. However, the positive impact on NIM shows that banks charge their customers for their credit card usage.

Conclusively, despite the fact that the issue of the relationship between and financial development and macroeconomic variables is becoming perennial yet it is also contentious. This is because the exact direction of causality between them is still controversial. Besides, most of the studies reviewed were on aggregate level. To the best of our knowledge, this study is one of the few studies that consider the relationship between financial innovation and economic growth at disaggregate level.

\section{SECTION THREE}

Methods and materials.

Model specification.

Since the prime focus of this study is to investigate the relationship between financial innovation and sectoral output of Nigerian economy, therefore the model for this study takes it root from the work of Olawale (2014) that studied the relationship between commercial banks performance and economic growth in Nigeria and also, with reference to empirical literature equation 3.1 is specified.

Where:

$$
\text { In } \mathrm{Y}_{1}=\alpha_{\alpha}+\beta_{1} \mathrm{InF}_{\mathrm{t}}+\beta_{2} \mathrm{INDCP}_{1}+\beta_{3} \mathrm{InDCF}_{\mathrm{t}}+{ }_{\mathrm{Et}}
$$

$\operatorname{In}\left(Y_{t}\right)$ is natural log of Gross Domestic Product per capital,

$\mathrm{InFI}_{\mathrm{t}}$ is natural log of financial innovation, variables.

$\alpha_{0}$ is a constant term,

$\beta_{1} \beta_{2}$ and $\beta_{y}$ are the coefficients of model

$t$ is for the period,

and $E_{t}$ denotes error correction term. This includes control variables such as: interest rate, total credit to private sector, gross fixed capital formation, inflation market capitalization and exchange rate.

This study employs quarterly data sources from various publications of Central Bank of Nigeria statistical Bulletin, and Bureau of statistics This study considers four sectors considered. The sectors are Agriculture, Manufacturer, Construction and Services.

\section{SECTION FOUR}

\section{RESULTS AND DISCUSSIONS}

Table 1: Summary of Unit Root Test Results:

\begin{tabular}{|l|l|l|l|l|l|l|l|}
\hline \multicolumn{9}{|l|}{ At Level } & \multicolumn{1}{l|}{ At First Difference } \\
\hline Variables & $\begin{array}{l}\text { ADF } \\
\text { statistics }\end{array}$ & $\begin{array}{l}1 \% \text { critical } \\
\text { value }\end{array}$ & $\begin{array}{l}5 \% \text { critical } \\
\text { value }\end{array}$ & ADF statistics & $\begin{array}{l}1 \% \text { critical } \\
\text { value }\end{array}$ & $\begin{array}{l}5 \% \text { critical } \\
\text { value }\end{array}$ & $\begin{array}{l}\text { Order } \\
\text { integration }\end{array}$ \\
\hline $\begin{array}{l}\text { RGDPgr } \\
\text { (Agric) }\end{array}$ & -0.775168 & -3.699871 & -2.976263 & $-11.47223^{*}$ & -3.699871 & -2.976263 & $\mathrm{I}(1)$ \\
\hline $\begin{array}{l}\text { RGDPgr } \\
\text { (Manu) }\end{array}$ & -1.524984 & -3.639407 & -2.951125 & $-3.746570^{*}$ & -3.639407 & -2.951125 & $\mathrm{I}(1)$ \\
\hline $\begin{array}{l}\text { RGDPgr } \\
\text { (Const) }\end{array}$ & -1.535423 & -3.639407 & -2.951125 & -3.140795 & -3.639407 & -2.951125 & $\mathrm{I}(1)$ \\
\hline $\begin{array}{l}\text { RGDPgr } \\
\text { (Serv) }\end{array}$ & -2.006492 & -3.670170 & -2.963972 & $-3.637860^{*}$ & -3.639407 & -2.951125 & $\mathrm{I}(1)$ \\
\hline POS & -1.925313 & -3.670170 & -2.963972 & $-4.567226^{*}$ & -3.670170 & -2.963972 & $\mathrm{I}(1)$ \\
\hline ATM & -2.724861 & -3.639407 & -2.951125 & $-4.997048^{*}$ & -3.639407 & -2.951125 & $\mathrm{I}(1)$ \\
\hline WEBP & -2.018333 & -3.639407 & -2.951125 & $-3.458389^{* *}$ & -3.639407 & -2.951125 & $\mathrm{I}(1)$ \\
\hline CPS & -2.067065 & -3.639407 & -2.951125 & $-3.258931^{* *}$ & -3.639407 & -2.951125 & $\mathrm{I}(1)$ \\
\hline MCAP & -2.339249 & -3.639407 & -2.951125 & $-3.727571^{*}$ & -3.639407 & -2.951125 & $\mathrm{I}(1)$ \\
\hline
\end{tabular}

Note: *(**) connote significance at $1 \%(5 \%)$ significant levels respectively

Source: Author's Computation, (2020) 
Unit root test results presented in table 4.1 showed the Augmented Dickey-Fuller test result for all the variables of interest used in the study. Result showed that the variables of interest were integrated of difference orders at level but they became stationary of the same order at first difference. That is integrated of order I(I) . Given the fact that all the variables of interest are integrated of the same order, Johansen co-integration test was conducted to ascertain the existence of long run relationship.

Table 2: Johansen Co-integration Test Result

\begin{tabular}{|c|c|c|c|c|}
\hline & & AGRIULTURAL SECTOR & & \\
\hline $\begin{array}{l}\text { Eigen } \\
\text { Value }\end{array}$ & $\begin{array}{l}\text { Trace } \\
\text { Statistics }\end{array}$ & $\begin{array}{l}5 \text { Percent Critical } \\
\text { Value }\end{array}$ & Probability & $\begin{array}{l}\text { Hypothesized No of } \\
\text { CE(s) }\end{array}$ \\
\hline None * & 0.640290 & 135.2257 & 95.75366 & 0.0000 \\
\hline At most $1 *$ & 0.600844 & 100.4622 & 69.81889 & 0.0000 \\
\hline At most $2 *$ & 0.502216 & 69.23650 & 47.85613 & 0.0002 \\
\hline At most $3 *$ & 0.408715 & 45.51850 & 29.79707 & 0.0004 \\
\hline At most $4 *$ & 0.385242 & 27.65298 & 15.49471 & 0.0005 \\
\hline At most $5 *$ & 0.278769 & 11.11108 & 3.841466 & 0.0009 \\
\hline \multicolumn{5}{|c|}{ Trace test indicates 6 co-integrating eqn(s) at the 0.05 level } \\
\hline & & MANUFACTURING SECTOR & & \\
\hline None * & 0.620968 & 124.5347 & 95.75366 & 0.0001 \\
\hline At most $1 *$ & 0.578531 & 91.55015 & 69.81889 & 0.0004 \\
\hline At most $2 *$ & 0.548959 & 62.17384 & 47.85613 & 0.0013 \\
\hline At most $3 *$ & 0.432319 & 35.10317 & 29.79707 & 0.0111 \\
\hline At most $4 *$ & 0.346694 & 15.85251 & 15.49471 & 0.0442 \\
\hline At most 5 & 0.039730 & 1.378388 & 3.841466 & 0.2404 \\
\hline \multicolumn{5}{|c|}{ Trace test indicates 5 co-integrating eqn(s) at the 0.05 level } \\
\hline & & CONSTRUCTION SECTOR & & \\
\hline None * & 0.598714 & 121.1963 & 95.75366 & 0.0003 \\
\hline At most $1 *$ & 0.567142 & 90.15155 & 69.81889 & 0.0005 \\
\hline At most $2 *$ & 0.513499 & 61.68182 & 47.85613 & 0.0015 \\
\hline At most $3 *$ & 0.443486 & 37.18425 & 29.79707 & 0.0059 \\
\hline At most $4 *$ & 0.366173 & 17.25810 & 15.49471 & 0.0269 \\
\hline At most 5 & 0.050303 & 1.754814 & 3.841466 & 0.1853 \\
\hline \multicolumn{5}{|c|}{ Trace test indicates 5 co-integrating eqn(s) at the 0.05 level } \\
\hline & & SERVICE SECTOR & & \\
\hline None * & 0.619770 & 129.9923 & 95.75366 & 0.0000 \\
\hline At most $1 *$ & 0.599567 & 97.11509 & 69.81889 & 0.0001 \\
\hline At most $2 *$ & 0.538785 & 65.99800 & 47.85613 & 0.0004 \\
\hline At most $3 *$ & 0.420126 & 39.68572 & 29.79707 & 0.0027 \\
\hline At most $4^{*}$ & 0.299969 & 21.15760 & 15.49471 & 0.0063 \\
\hline At most $5 *$ & 0.233294 & 9.032172 & 3.841466 & 0.0027 \\
\hline
\end{tabular}

* denotes rejection of the hypothesis at $1 \%$ significance level

Source: Author's computation, (2020)

Summary of co-integration test result on presented table 4.2 showed that there is enough evidence to reject the null hypothesis of no co-integration equation in favour of 6 co-integrating equations for Agricultural sector, 5 cointegrating equation for manufacturing sector, 5 cointegrating equation for construction sector and 6 cointegrating equation for service sector respectively.

VECM IMPULSE ANALYSIS

Given that the variables of interest in the long-run are co-integrated, this study then employed Vector Error Correction Model (VECM) to track the response of sectoral output measured in terms of sectoral GDP growth rate to both financial innovation in Nigeria. Notably, the estimated VECM is interpreted via the impulse response and forecast error variance decomposition for agricultural sector, manufacturing sector, construction sector and service sector respectively. For, simplicity of presentation, this study presents the impulse response in difference figures below the summary of variance decomposition of sectoral output for all the sector is presented in 4.3 
Figure 4.1: Impulse Response (Agricultural Sector)

Response to Cholesky One S.D. Innovations

Response of RGDPGR to LNPOS

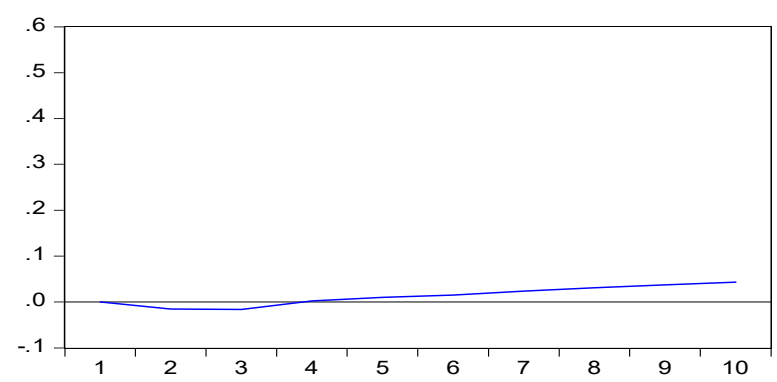

Response of RGDPGR to LNWEBP

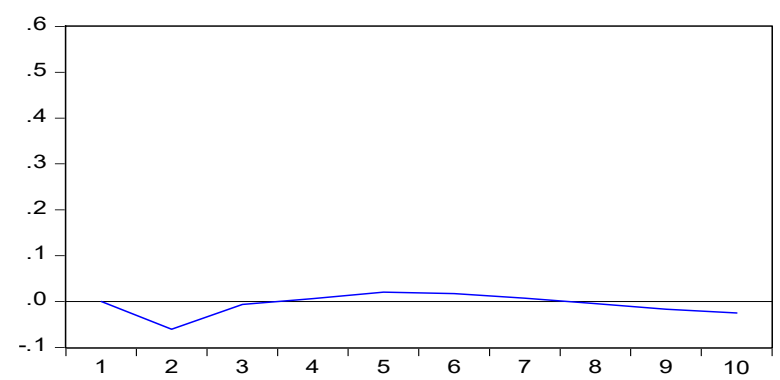

Response of RGDPGR to LNMCAP

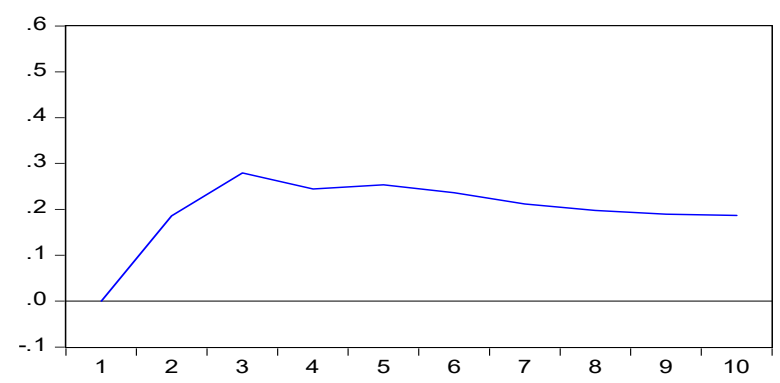

Response of RGDPGR to LNATM

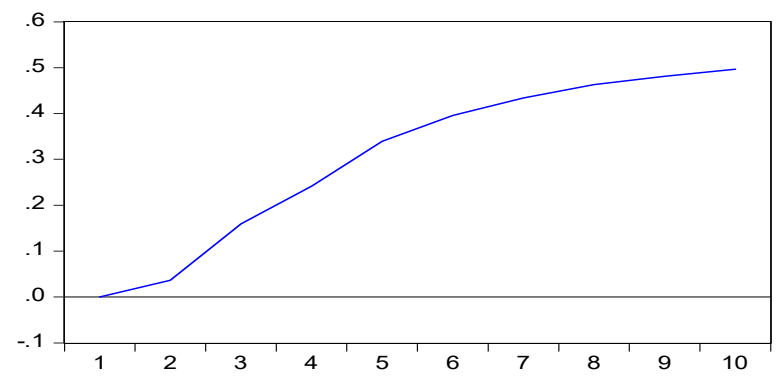

Response of RGDPGR to LNCPS

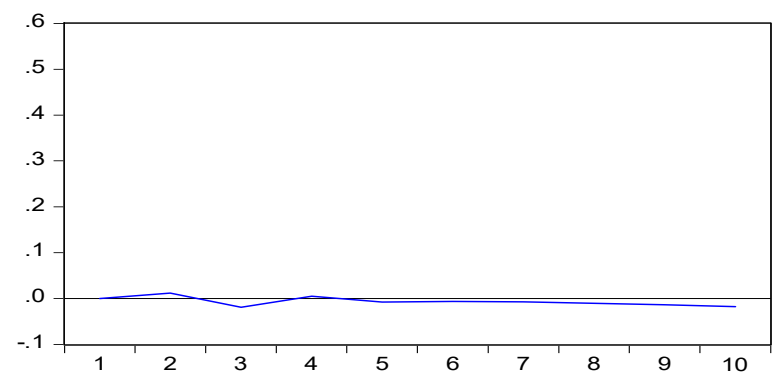

Figure 4.1 revealed response of agricultural sector output to one standard deviation shock in automated teller machine transaction (ATM), point o sales transactions (POS) web based transaction (WEBP), commercial banks credit to private sector and market capitalization overview of figure 4.1, reflects that financial innovation variables related to technological innovation (POS, WEBP) has neutral influence on the output of agricultural sector, while the influence of ATM is substantial over the 10 period time horizon. Market capitalization (a measure of business innovation as a subset of financial innovation) has progressive positive influence on output of agricultural sector as the response of RGDPgr of the sector to one standard deviation remained positive from period 1 to period 10 . However, response of agricultural output growth rate to one standard deviation shock in commercial banks credit to private sector remained neutral over the time period horizon, thus, reflecting that commercial bank lending behavior has not noticeable influence of output growth of Nigeria agricultural sector 
Figure 3.2: Impulse Response (Manufacturing Sector)

Response to Cholesky One S.D. Innovations

Response of RGDPGR to LNPOS

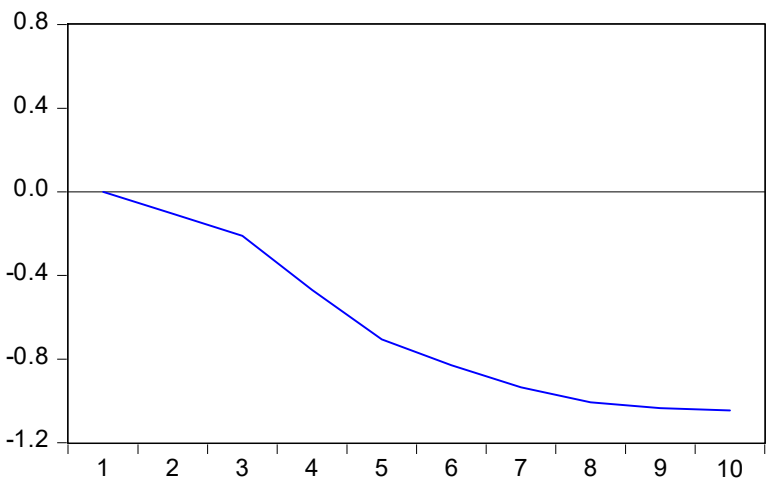

Response of RGDPGR to LNWEBP

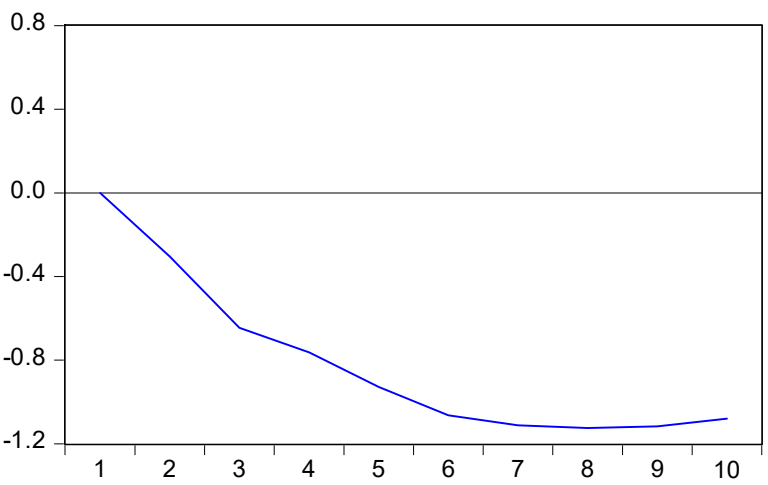

Response of RGDPGR to LNATM

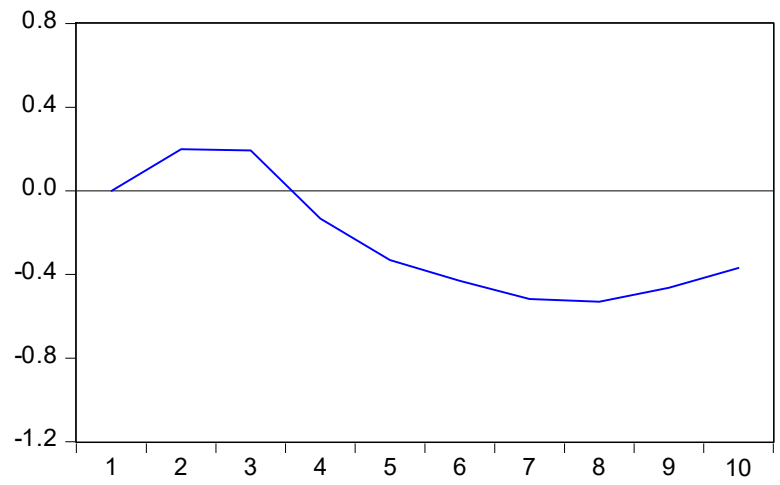

Response of RGDPGR to LNCPS

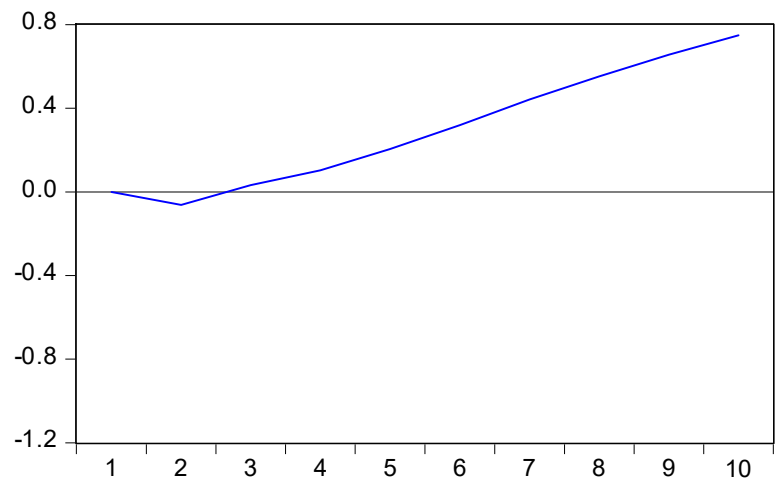

Response of RGDPGR to LNMCAP

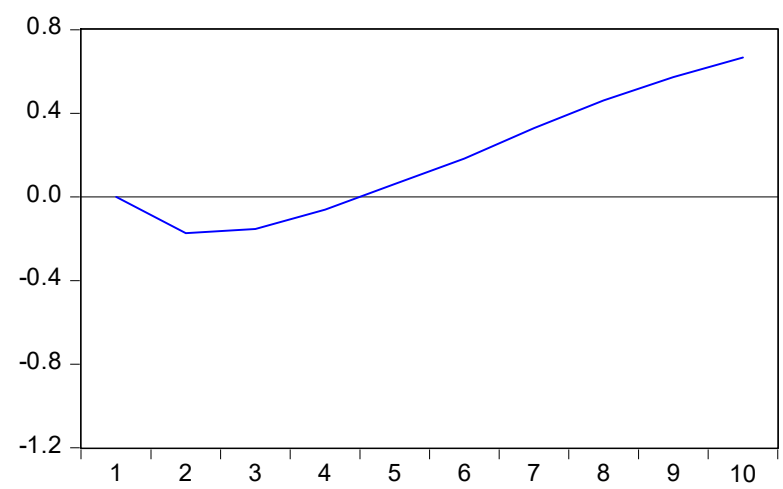

Impulse response presented in figure 2 revealed response of manufacturing sector output to one standard deviation shock in financial innovation measured in terms of transaction related to automated teller machine (ATM), point of sales (POS) and web based payment (WEBP) and commercial bank lending behavior in terms of credit to private sector alongside market capitalization. As shown in figure 2 output growth of manufacturing sector responded negatively to one standard deviation shock in financial innovation in the country both in the immediate time horizon and the future as output growth declined from period 1 through period for all the corresponding financial innovation variables.

On the other hand, manufacturing output responded positively to one standard deviation shock in both commercial bank credit to private sector and the level of market capitalization in the country. observably, the positively response is progressive and consistent especially over the time horizon from period 4 to 10 for both CPS and MCAP, which reflect that Commercial Bank's lending behaviour and business innovation as a subset of financial innovation exert substantial influence on output growth of the manufacturing sector more as compared to the negative influence of technological innovation in financial transaction in terms of ATM, POS and WEBP 
transaction.

Figure 3: Impulse Response (Construction Sector)

Response to Cholesky One S.D. Innovations

Response of RGDPGR to LNPOS

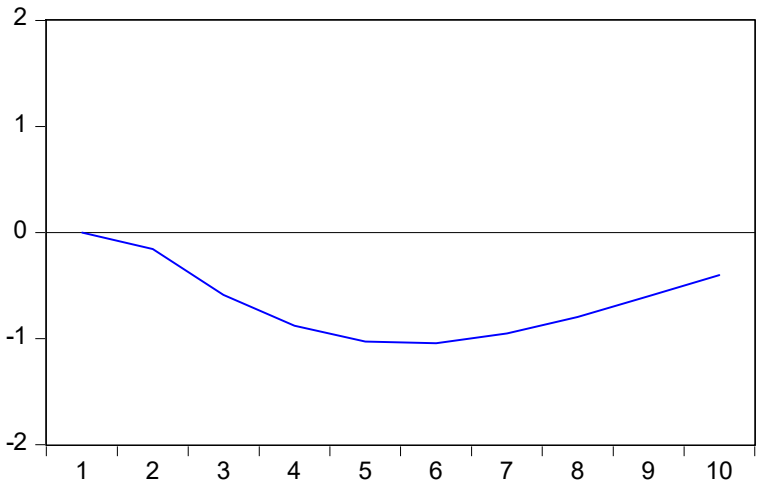

Response of RGDPGR to LNWEBP

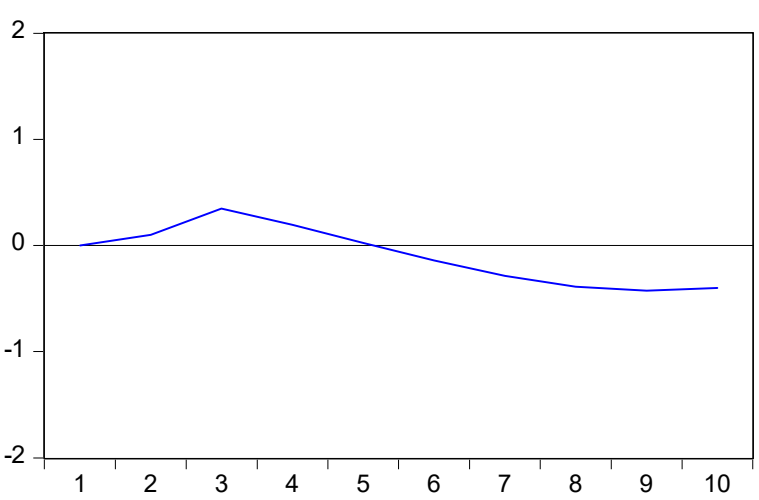

Response of RGDPGR to LNATM

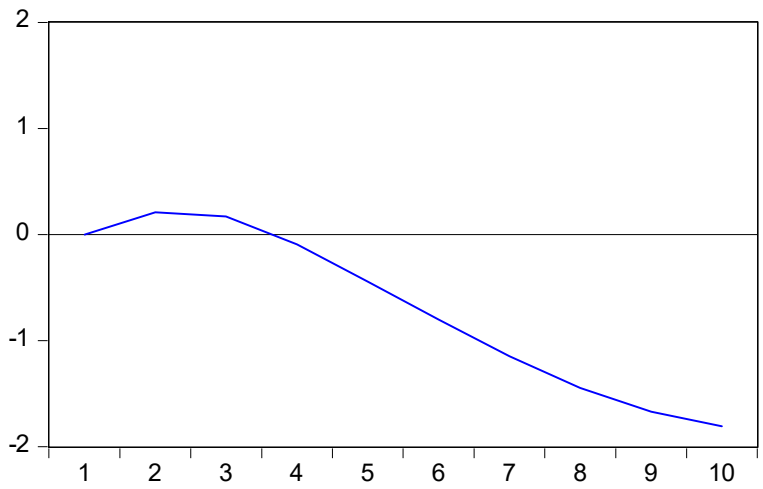

Response of RGDPGR to LNCPS

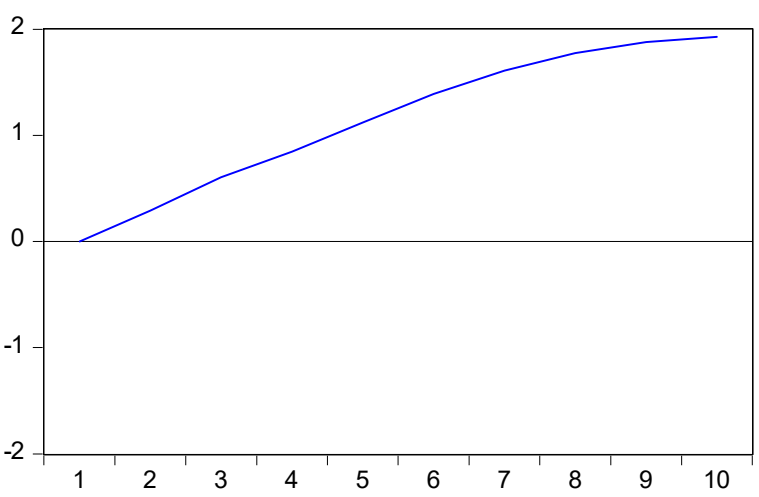

Response of RGDPGR to LNMCAP

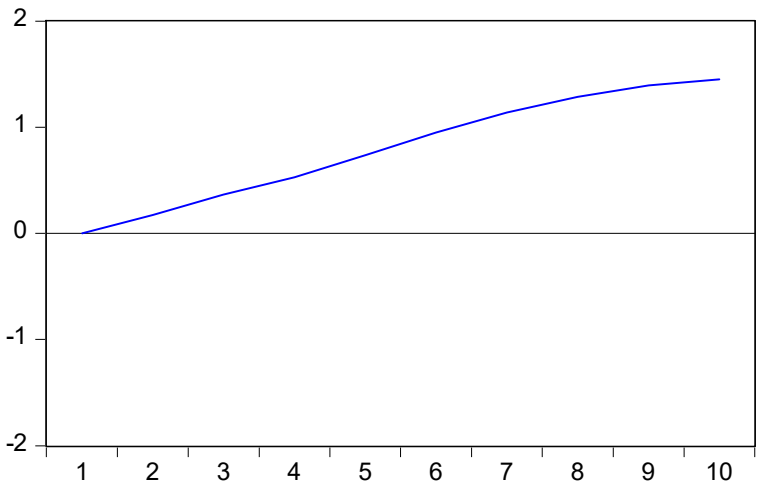

Figure 4.3 revealed output growth of construction sector respond to one standard deviation shock in technological innovation, business innovation and commercial bank's lending behaviour. As shown in figure 4.3, output growth of construction sector responded negatively to technological innovation subset of financial innovation as measured in terms of ATM, POS and WEBP transactions. The figure revealed that output growth of construction sector decline largely over the 10 years horizon. On the other hand output growth of the sector responded positively to one standard deviation shock in both business innovation in terms of market capitalization and commercial bank lending behaviour in terms of credit to private sector 
Figure 4.3: Impulse Response (Service Sector)

Response to Cholesky One S.D. Innovations

Response of RGDPGR to RGDPGR

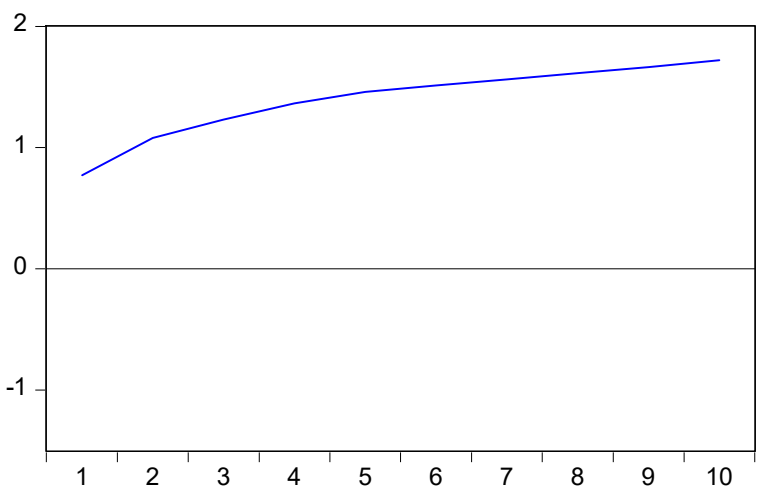

Response of RGDPGR to LNATM

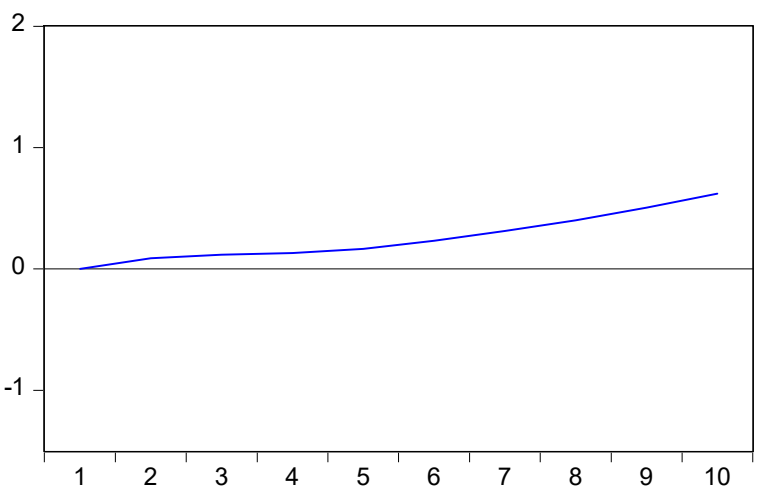

Response of RGDPGR to LNCPS

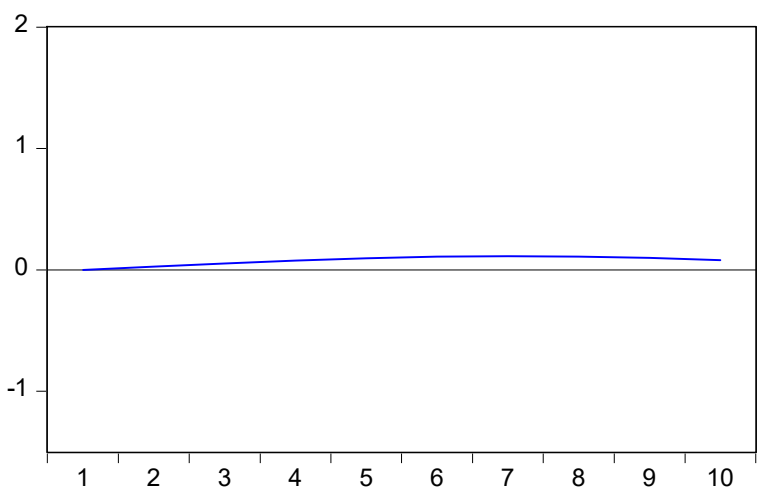

Response of RGDPGR to LNPOS

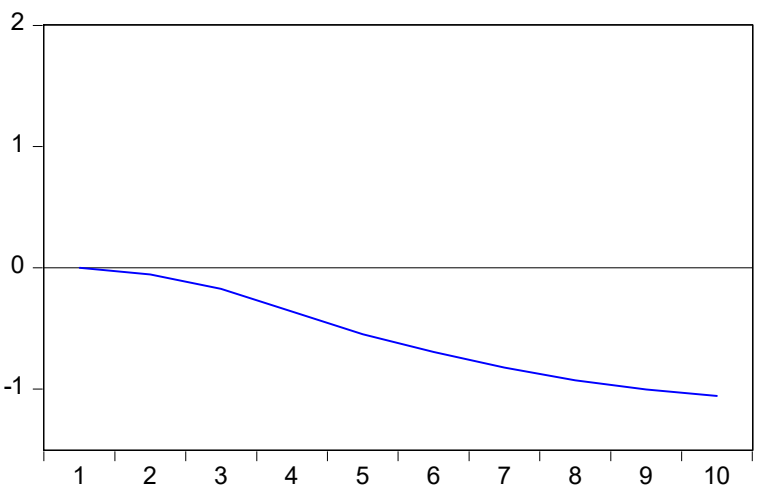

Response of RGDPGR to LNWEBP

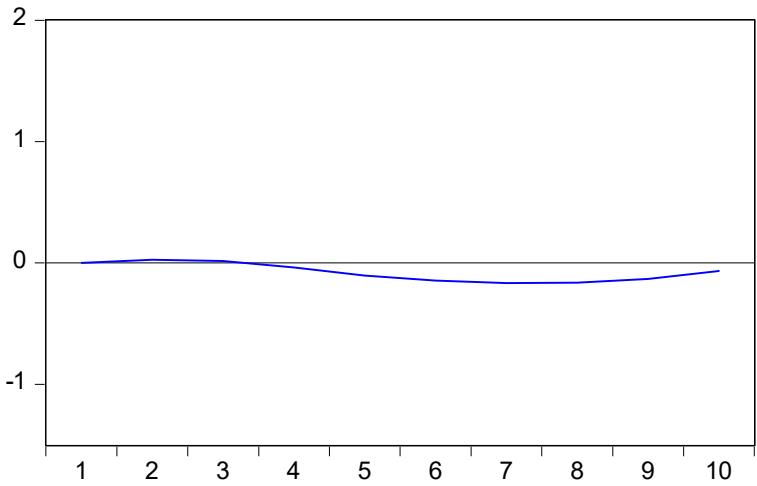

Response of RGDPGR to LNMCAP

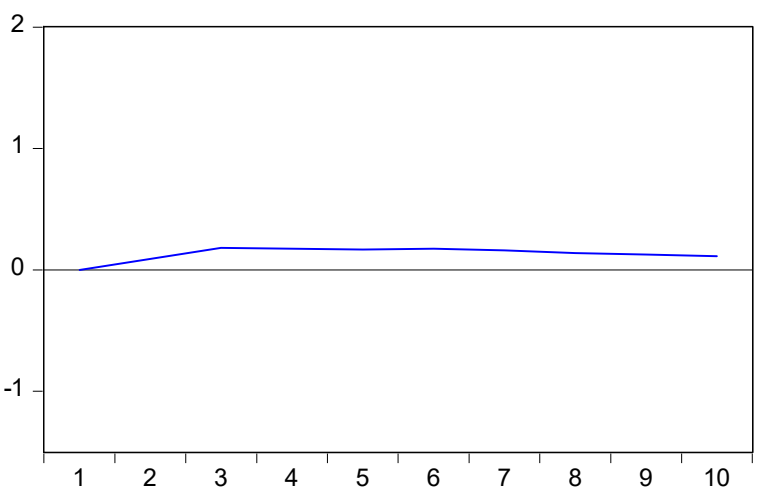

Figure 4.4 showed the response of service sector output growth to innovative shock in ATM, POS, WEBP (measures technological financial innovation) MCAP (business financial innovation) and CPS (commercial bank lending behaviour). As shown in the figure 4.4, output growth of the sector response positively and progressively to one standard deviation shock in ATM transactions, but negatively to both POS and WEBP transactions, while it responded positively but mildly to both market capitalization and commercial banks credit to private over the 10 years period. This result reflects that financial innovation in terms of technological innovation and business innovation as well as Banks lending behaviour have limited influence on the output growth of Nigerian service sector 
Table 3: Summary of Variance Decomposition

Agricultural Sector

Variance Decomposition of RGDPgr

\begin{tabular}{|l|l|l|l|l|l|l|l|}
\hline Period & S.E. & RGDPgr & POS & ATM & WEBP & CPS & MCAP \\
\hline 1 & 0.543184 & 100.0000 & 0.000000 & 0.000000 & 0.000000 & 0.000000 & 0.000000 \\
\hline 10 & 2.722489 & 77.10856 & 0.075652 & 16.69319 & 0.073531 & 0.017725 & 6.031342 \\
\hline
\end{tabular}

Manufacturing Sector

Variance Decomposition of RGDPgr

\begin{tabular}{|l|l|l|l|l|l|l|l}
\hline Period & S.E. & RGDPgr & POS & ATM & WEBP & CPS & MCAP \\
\hline 1 & 1.681056 & 100.0000 & 0.000000 & 0.000000 & 0.000000 & 0.000000 & 0.000000 \\
\hline 10 & 10.19086 & 82.99161 & 5.318306 & 1.245266 & 7.715870 & 1.586765 & 1.142184 \\
\hline
\end{tabular}

Construction Sector

Variance Decomposition of RGDPgr

\begin{tabular}{|l|l|l|l|l|l|l|l|}
\hline Period & S.E. & RGDPgr & POS & ATM & WEBP & CPS & MCAP \\
\hline 1 & 1.865619 & 100.0000 & 0.000000 & 0.000000 & 0.000000 & 0.000000 & 0.000000 \\
\hline 10 & 10.24374 & 59.24125 & 5.109832 & 9.922032 & 0.728164 & 16.53132 & 8.467400 \\
\hline
\end{tabular}

Service Sector

Variance Decomposition of RGDPgr

\begin{tabular}{|l|l|l|l|l|l|l|l|}
\hline Period & S.E. & RGDPgr & POS & ATM & WEBP & CPS & MCAP \\
\hline 1 & 0.770788 & 100.0000 & 0.000000 & 0.000000 & 0.000000 & 0.000000 & 0.000000 \\
\hline 10 & 5.132471 & 77.17776 & 17.53667 & 3.835399 & 0.423740 & 0.266739 & 0.759686 \\
\hline
\end{tabular}

SOURCE: Author's Computation (2020)

Variance decomposition summary presented in Table 4 revealed the $1^{\text {st }}$ and $10^{\text {th }}$ period contribution of financial innovation variables, and commercial bank's lending behaviour measure to forecast error variance of output growth rate across agricultural, manufacturing, construction and service sector of Nigerian economy.

Agricultural sector result showed that in the first period output growth accounted for about $100 \%$ of its forecast error variance, while financial innovation variables bank lending behavior measure could not account for any portion of it forecast error variance. However, over time up to period 10 output growth declined in its contribution to its own forecast error variance, giving up about $0.07 \%$ to point of sales (POS), $16.69 \%$ to automated teller machine transaction (ATM), $0.07 \%$ to Web based payment transactions (WEBP), $0.017 \%$ to credit to private sector (CPS) and $6.03 \%$ to market capitalization (MCAP). This result showed that on the short run, output growth is strongly endogenous exerting absolute influence on itself, but as time passes into the intermediate and long run, part of it forecast error variance was accounted for by financial innovation variables and commercial Banks lending behavior especially the likes of Automated teller machine transaction and market capitalization. Hence in the discourse of output growth of agricultural sector, both financial innovation measured in terms of ATM (technological innovation) and MCAP (Business innovation) are on the long run least exogenous as they accounted for notable percentage of the forecast error variance in output growth of the sector.

For manufacturing sector, output growth accounted for $100 \%$ of its forecast error variance in period 1 and $82.99 \%$ in period 10 . On the other hand, financial innovation variables and Bank's lending variable could not account of any percentage of the forecast error variance in output growth of the sector in period 1, but at period 10 POS account for 5.31\% ATM accounted for 1.24\%, WEBP accounted for $7.71 \%$, CPS accounted for $1.58 \%$ while MCAP accounted for $1.14 \%$. overview of the contribution of financial innovation variable to forecast error variance in output growth of manufacturing sector reflect that only POS and WEBP could be considered to be least exogenous in the discourse output growth of manufacturing sector in the intermdiate/long runs

For construction sector, result showed that output growth accounted for $100 \%$ of its forecast error variance in period 1 , while in period 10 it accounted for $59.24 \%$, giving about $5.10 \%$ up for POS, $9.92 \%$ for ATM, $0.72 \%$ for WEBP, $16.53 \%$ for CPS, and $8.46 \%$ for MCAP in period 10 . Notably result showed that financial innovation and Bank's lending behavior has not traceable contribution to forecast error variance of output growth of construction sector in the initial stage (short run), but over the passage of time POS and ATM (technological innovation) MCAP (business innovation) and CPS (commercial bank lending behavior) contributes notable percentage to forecast error variance of output growth in the sector

For service sector $100 \%$ and $77.17 \%$ of the forecast error variance in output growth can be accounted for by RGDPgr itself in period 1 and period 10, while POS accounted for $17.53 \%$ in period 10, ATM accounted for $3.83 \%$ in period 10 , WEBP accounted for $0.43 \%$ in period, CPS accounted for $0.266 \%$ in period 10 and MCAP accounted for $0.759 \%$ in period 10 .the result showed that on the long run only financial innovation in terms of POS, and ATM has notable influence on the forecast error variance of output growth of the service sector. 


\section{Summary and Conclusion}

The study investigated the relationship between financial innovation and sectoral real output of the Nigerian economy between 1990 to 2018 using quarterly data which were sourced from various publications of Central Bank of Nigeria and Bureau of Statisitcs. The study employed Vector Error correction model as estimation technique. Results obtained from co-integration showed long-run co-movement among the variables of interest. The impulse reponse function results showed that sectoral real output responded heterogeneously to shocks emanating from financial innovation variables. take for instance, both manufacturing and Agricultural sectoral output responded positively and significantly to shocks coming them financial innovation while responses of service and construction sectors were positive but insignificant. Also, Results from variance decomposition showed that the most influential variables of financial innovation on secotral real output are point of sales transaction and automated teller machine. Based on these findings, the study concludes that financial innovation has moderate effects on sectoral real output in Nigeria. The study recommends that more regulatory guidelines, should be provided for financial institutions to perform their financial intermediation functions effectively.

\section{REFERENCES}

Abernathy, W. J. \& J.M., (1998). Patterns of industrial innovations, Technology Review, (80), 75-79.

Abu-Bader, S. and Abu-Qarn, A. M. (2008), - Financial development and economic growth: empirical evidence from MENA countries//, Review of Development Economics 12.803-817.

Acaravci S.K., I. Ozturk and A. Acaravci (2009). - financial development and economic growth: literature survey and empirical evidence from sub-Saharan African countries// SAJEMS NS 12 (2009) No 111

Antony, P. \& Antony A. (2014). Financial Innovations and Economic Growth in Ghana: Evidence from Autoregressive Distributive Lags (ARDL) and Granger Causality Approaches

Bara A. Mudxingiri C (2016) Financial innovation and economic growth: evidence from Zmbabwe, Invest Manage Financial Innovation 13(2): 65-75.

Bayraktar, N., \& Wang Y. (2006). Banking sector openness and economic growth. World Bank Policy Research Working paper 4019.

Chou YK, ChinMS (2011) Financial innovations and endogenous growth. J Econ Manage 25(2):25-40.

Dahou K, Omar H.I., Pfister M (2009) Deepening African financial markets for growth. The Arica competitiveness report, Publication, World Economic Forum, World Bank, African Development Bank Web.

Damanpour F (20090 Combinative effects of innovation types and organizational performance: a longitudinal study of service organization: Journal of Management Studies.

Egesa, K. A. and Abuka, C.A., (12007). The analysis of total factor productivity (TFP) change and its determinants among Ugandan banks. The Bank of Uganda Staff Paper Journal, Vol. 1 (2), pp.78-103.

Engel \& Granger (1997). An Introduction to stochastic unit-root processes. Journal of Econometrics, Vol. 80, issue $1,35-62$.

Fries, J. \& Obrien, C. (1998) Industrial design and Innovation in Mexican enterprises (Internet), Available from: http://www.idemployee.id.tue.nl/g.w.,.rauterberg/conferences [Accessed 21 December 2010]

Guryay E., O. V. Safakli and B. Tuzel (2007), "Financial development and economic growth: Evidence from Northern Cyprus". International Research Journal of Finance and Economics ISSN 1450-2887 Issue 8

Hassan, I., Renzis, T. D., \& Schmiedel, H. (2013) Retail payments and Real Economy. European Central Bank, Working Paper Series No. 1572.

Kopcke.Hye, O., \& Adnan, M. (2009). Financial innovation and demand for money in Pakistan. Asian Economic Review 51(2), 219-228.

Joshua Abor (2005). Technological innovations and banking in Ghana: An evaluation of customers' perceptions. Arican Journal Online. Retrieved from

Levine, R. (2005). Finance and growth: Theory and evidence. In P. Aghion \& S. Durlauf (Eds.), Handbook of Economci Growth, 1 (pp. 865-934). Amsterdam, Netherlands: Elsevier.

Meierrieks, D. (2014). Financial development and innovation: Is there evidence of a Schumpeterian financeinnovation nexus? Annals of Economics and Finance 15(2), 343-363.

Ndebbio (2000) "Fiscal Operations, Moneey Supply and Inflationary Developments in Nigeria" in Ekpo H.I (Eds) Monetary and Fiscal Policies During the Structural Adjustment Programme. Proceedings of Seminar. AERC/CBN

Ndlovu I, Siyavora A (2014). Impact of internet banking on the Zimbabwean Banking sector: An application of the multinominal logitutidinal modeling. International. Journal of Economics of Commerce Management. United Kingdom. 2(8):1-17

James K. M (2014. Effects of Financial innovation on the financial performance of commercial Banks in Kenya Internaitonal Journal of Humanities and social science Vol. 4 No 7

Aysel Gundogdu and Fatima Dilvin TASKIn (2017). Analysis of the relationship between financial innovation and the performance of Turkish Banking system International Review of Economics and management Vol 5, 
PP 16-32.

Domeher, D. Frimpong I M and Appiah T (2015) Adoption of Financial innovation in the Ghanaian banking industry Africa Review of Economics and finance 6(2) 88-114.

Mustapha A. Akinkunbi (2017) Determinants of Banks profitability in Nigeria: Does Relative market power matter? Journal of finance and Bank management vol. 5 No. 1 PP $42-53$. 